\title{
Ideological Reversal among Supreme Court Justices
}

\author{
Daniel G. Klemonski, Oliver K. Natarajan, Samuel H. Studnitzer, Paul M. Sommers* \\ Department of Economics, Middlebury College, Middlebury, VT, USA \\ Email: *psommers@middlebury.edu
}

How to cite this paper: Klemonski, D.G., Natarajan, O.K., Studnitzer, S.H. and Sommers, P.M. (2017) Ideological Reversal among Supreme Court Justices. Open Journal of Social Sciences, 5, 290-299. https://doi.org/10.4236/jss.2017.57018

Received: June 29, 2017

Accepted: July 17, 2017

Published: July 20, 2017

Copyright @ 2017 by authors and Scientific Research Publishing Inc. This work is licensed under the Creative Commons Attribution International License (CC BY 4.0).

http://creativecommons.org/licenses/by/4.0/ (c) (†) Open Access

\begin{abstract}
The purpose of this paper is to assess ideological change of Supreme Court justices from 1937 to 2015. Using Martin-Quinn scores, we find that for most four-year presidential terms, Democratic president Court appointees are more liberal and Republican president appointees are more conservative. Yet among justices with a minimum tenure of seven years, simple bilinear regression on a time trend variable shows that ten of eighteen justices appointed by Republican presidents have drifted to the left, while seven of sixteen justices appointed by Democratic presidents have drifted to the right. We conclude that ideological drift among justices, especially in a direction contrary to what the appointing president might have predicted, appears to be more common than exceptional.
\end{abstract}

\section{Keywords}

Supreme Court Justices, Martin-Quinn Scores, Regression

\section{Introduction}

The recent confirmation of Neil Gorsuch to the U.S. Supreme Court (April 7, 2017) following a 14-month vacancy created after the death of Justice Antonin Scalia begs the question: How many more opportunities will President Donald Trump have to appoint another justice to the Supreme Court? Article II, Section 2, Clause 2 of the U.S. Constitution gives the president the pro forma power to nominate judges to the Supreme Court. However, given the lifetime tenure of Supreme Court justices, it is difficult to predict when a president will be presented with a Court vacancy. After all, an appointment to the Supreme Court can only occur after a sitting justice dies, resigns, or retires. Five current justices (as of July 1,2017) are older than 65 years of age-Samuel Alito (67), Clarence Thomas (69), Stephen Breyer (78), Anthony Kennedy (80), and Ruth Bader 
Ginsburg (84). Thus, the remainder of President Donald Trump's term could resemble that of Presidents William H. Harrison, Zachary Taylor, Andrew Johnson, and Jimmy Carter-all of whom made no appointments at all to the highest judicial body in the land-or his remaining time in office might more closely resemble that of the six presidents who successfully appointed five or more members to the Court (Gunther [1], Appendix B). ${ }^{1}$ Nevertheless, the power of appointment is by no means absolute, as the president requires the consent of (that is, a simple majority vote in) the Senate.

We examine the extent of political harmony between presidents and their successful appointees. One would expect that Republican presidents would appoint conservative justices and Democratic presidents would appoint liberals. Presidents nominate kindred spirits who will, they hope, hold the same ideology for as long as they serve on the Court. But, does the judicial ideology of Supreme Court justices change over time? Is ideological drift among Supreme Court justices likely even in the absence of membership turnover? Do justices appointed by Democratic (Republican) presidents become more liberal (conservative)? Or, is there often a reversal in ideology during their tenure on the Court?

In this paper, we use Martin-Quinn (hereafter abbreviated M-Q) measures of judicial ideology to compare M-Q averages between Republican- and Democratic-appointed justices, and to determine whether $\mathrm{M}-\mathrm{Q}$ justice-specific scores change over time.

\section{The Data}

Martin and Quinn [2] estimated ideological scores for every Supreme Court justice for every term between October 1937 (during Franklin D. Roosevelt's second presidential term) and October 2015 (during Barack Obama's second term). A negative M-Q score reflects liberal ideology whereas a positive $M-Q$ score reflects a conservative ideology. In general, higher values represent greater conservatism. The updated M-Q scores through 2015 can be found at [3]. The data set includes M-Q scores (referred to by Martin and Quinn as the justice's "posterior mean") for 22 different Democratic appointees who collectively served a total of 321 years (mean: -1.0216, standard deviation: 2.0898) and 23 Republican appointees who collectively served a total of 398 years (mean: 0.7074, standard deviation: 1.8435). For all 45 Supreme Court justices, Table 1 shows their mean M-Q score over the time they served on the Supreme Court, the start and ending dates of their tenure, the length of their tenure (in days), and the name and party affiliation of the president who appointed them. ${ }^{2}$

Table 2 shows the top five most liberal (largest negative M-Q score) and most conservative (largest positive M-Q score) justices classified by the political party of the appointing president. Harry S. Truman appointed four justices during his

${ }^{1}$ The six presidents include (number of appointments in parentheses): George Washington (10), Franklin D. Roosevelt (9), William H. Taft (6), Andrew Jackson (5), Abraham Lincoln (5), and Dwight D. Eisenhower (5).

${ }^{2}$ Thirty-seven of the 45 justices completed their entire terms of service between the 1937 and 2015 terms inclusive. 
Table 1. Martin-Quinn Scores of Supreme Court Justices, 1937-2015.

\begin{tabular}{|c|c|c|c|c|c|}
\hline \multirow{2}{*}{ Justice } & \multirow{2}{*}{ Martin-Quinn Score ${ }^{\mathrm{a}}$} & \multicolumn{2}{|c|}{ Tenure } & \multirow{2}{*}{ Days } & \multirow{2}{*}{ Appointed by } \\
\hline & & Start & End & & \\
\hline James C. McReynolds & 3.46925 & Aug. 29, 1914 & Jan. 31, 1941 & 9653 & Woodrow Wilson (D) \\
\hline Louis Brandeis & -0.61750 & Jun. 1, 1916 & Feb. 13, 1939 & 8293 & Woodrow Wilson (D) \\
\hline George Sutherland & 1.57400 & Sep. 5, 1922 & Jan. 17, 1938 & 5614 & Warren G. Harding (R) \\
\hline Pierce Butler & 2.22050 & Dec. 21,1922 & Nov. 16, 1939 & 6175 & Warren G. Harding (R) \\
\hline Harlan F. Stone & 0.01367 & Feb. 5, 1925 & Apr. 22, 1946 & 7748 & Calvin Coolidge (R) \\
\hline \multirow[t]{2}{*}{ Charles E. Hughes } & & Oct. 10,1910 & Jun. 10, 1916 & 2071 & William H. Taft (R) \\
\hline & 0.17925 & Feb. 24, 1930 & Jun. 30, 1941 & 4145 & Herbert Hoover (R) \\
\hline Owen J. Roberts & 1.53338 & May 20, 1930 & Jul. 31, 1945 & 5552 & Herbert Hoover (R) \\
\hline Benjamin N. Cardozo & -1.59800 & Mar. 2, 1932 & Jul. 9, 1938 & 2321 & Herbert Hoover (R) \\
\hline Hugo Black & -1.75868 & Aug. 18, 1937 & Sep. 17,1971 & 12,449 & F. D. Roosevelt (D) \\
\hline Stanley F. Reed & 0.37845 & Jan. 27, 1938 & Feb. 25, 1957 & 6970 & F. D. Roosevelt (D) \\
\hline Felix Frankfurter & 0.49954 & Jan. 20, 1939 & Aug. 28, 1962 & 8622 & F. D. Roosevelt (D) \\
\hline William O. Douglas & -4.64892 & Apr. 15, 1939 & Nov. 12, 1975 & 13,361 & F. D. Roosevelt (D) \\
\hline Frank Murphy & -1.58740 & Jan. 18, 1940 & Jul. 19, 1949 & 3471 & F. D. Roosevelt (D) \\
\hline James F. Byrnes & -0.19000 & Jul. 8, 1941 & Oct. 3,1942 & 453 & F. D. Roosevelt (D) \\
\hline Robert H. Jackson & 0.69769 & Jul. 11, 1941 & Oct. 9,1954 & 4839 & F. D. Roosevelt (D) \\
\hline Wiley B. Rutledge & -1.41543 & Feb. 11, 1943 & Sep. 10, 1949 & 2404 & F. D. Roosevelt (D) \\
\hline Harold H. Burton & 1.04464 & Sep. 22, 1945 & Oct. 13,1958 & 4770 & Harry S. Truman (D) \\
\hline Fred M. Vinson & 1.04643 & Jun. 24, 1946 & Sep. 8, 1953 & 2604 & Harry S. Truman (D) \\
\hline Tom C. Clark & 0.50367 & Aug. 19, 1949 & Jun. 12, 1967 & 6507 & Harry S. Truman (D) \\
\hline Sherman Minton & 1.12325 & Oct. 12,1949 & Oct. 15,1956 & 2561 & Harry S. Truman (D) \\
\hline Earl Warren & -1.25781 & Oct. 5, 1953 & Jun. 23, 1969 & 5741 & Dwight D. Eisenhower (R) \\
\hline John M. Harlan II & 1.62453 & Mar. 17, 1955 & Sep. 23, 1971 & 6035 & Dwight D. Eisenhower (R) \\
\hline William J. Brennan & -1.93403 & Oct. 15,1956 & Jul. 20, 1990 & 12,332 & Dwight D. Eisenhower (R) \\
\hline Charles E. Whittaker & 1.23533 & Mar. 22, 1957 & Mar. 31, 1962 & 1836 & Dwight D. Eisenhower (R) \\
\hline Potter Stewart & 0.43752 & Oct. 14,1958 & Jul. 3, 1981 & 8299 & Dwight D. Eisenhower (R) \\
\hline Byron White & 0.42313 & Apr. 16, 1962 & Jun. 28, 1993 & 11,397 & John F. Kennedy (D) \\
\hline Arthur Goldberg & -1.05367 & Sep. 28, 1962 & Jul. 26, 1965 & 1033 & John F. Kennedy (D) \\
\hline Abe Fortas & -1.43500 & Oct. 4,1965 & May 14, 1969 & 1319 & Lyndon B. Johnson (D) \\
\hline Thurgood Marshall & -2.81267 & Oct. 2,1967 & Oct. 1, 1991 & 8766 & Lyndon B. Johnson (D) \\
\hline Warren E. Burger & 1.86065 & Jun. 23, 1969 & Sep. 26, 1986 & 6305 & Richard M. Nixon (R) \\
\hline Harry Blackmun & -0.03036 & Jun. 9, 1970 & Aug. 3, 1994 & 8822 & Richard M. Nixon (R) \\
\hline Lewis F. Powell & 0.94206 & Jan. 7, 1972 & Jun. 26, 1987 & 5650 & Richard M. Nixon (R) \\
\hline William Rehnquist & 2.94803 & Jan. 7, 1972 & Sep. 3, 2005 & 12,295 & Richard M. Nixon $(\mathrm{R})^{\mathrm{b}}$ \\
\hline John P. Stevens & -1.82100 & Dec. 19,1975 & Jun. 29, 2010 & 12,612 & Gerald Ford (R) \\
\hline Sandra D. O'Connor & 0.98084 & Sep. 25, 1981 & Jan. 31, 2006 & 8895 & Ronald W. Reagan (R) \\
\hline Antonin Scalia & 2.46753 & Sep. 26, 1986 & Feb. 13, 2016 & 10,733 & Ronald W. Reagan (R) \\
\hline Anthony Kennedy & 0.69724 & Feb. 18, 1988 & & $10,697^{\mathrm{c}}$ & Ronald W. Reagan (R) \\
\hline David Souter & -0.78668 & Oct. 9,1990 & Jun. 29, 2009 & 6839 & George H. W. Bush (R) \\
\hline Clarence Thomas & 3.52348 & Oct. 23, 1991 & & $9354^{\mathrm{c}}$ & George H. W. Bush (R) \\
\hline Ruth B. Ginsburg & -1.54504 & Aug. 10, 1943 & & $8697^{\mathrm{c}}$ & Bill Clinton (D) \\
\hline Stephen Breyer & -1.13214 & Aug. 3, 1994 & & $8339^{c}$ & Bill Clinton (D) \\
\hline John Roberts & 1.11064 & Sep. 29, 2005 & & $4264^{\mathrm{c}}$ & George W. Bush (R) \\
\hline Samuel Alito & 1.66036 & Jan. 31, 2006 & & $4140^{c}$ & George W. Bush (R) \\
\hline Sonia Sotomayor & -2.04200 & Aug. 8, 2009 & & $2855^{\mathrm{c}}$ & Barack Obama (D) \\
\hline Elena Kagan & -1.52967 & Aug. 7, 2010 & & $2491^{\mathrm{c}}$ & Barack Obama (D) \\
\hline
\end{tabular}

Source: All Martin-Quinn scores are from the 2015 Supreme Court justice data file at http://mqscores.berkeley.edu/measures.php. We used the posterior mean score to represent the "ideal point" estimate of each justice each term (or year). ${ }^{\mathrm{a}}$ Martin-Quinn scores are based on terms of service since 1937. ${ }^{\mathrm{b} W i l}-$ liam Rehnquist began his tenure as chief justice (appointed by Ronald Reagan) on September 26, 1986. 'All figures are as of June 1, 2017. 
Table 2. Five Most Liberal and Conservative Justices Appointed by Democratic and Republican Party Presidents.

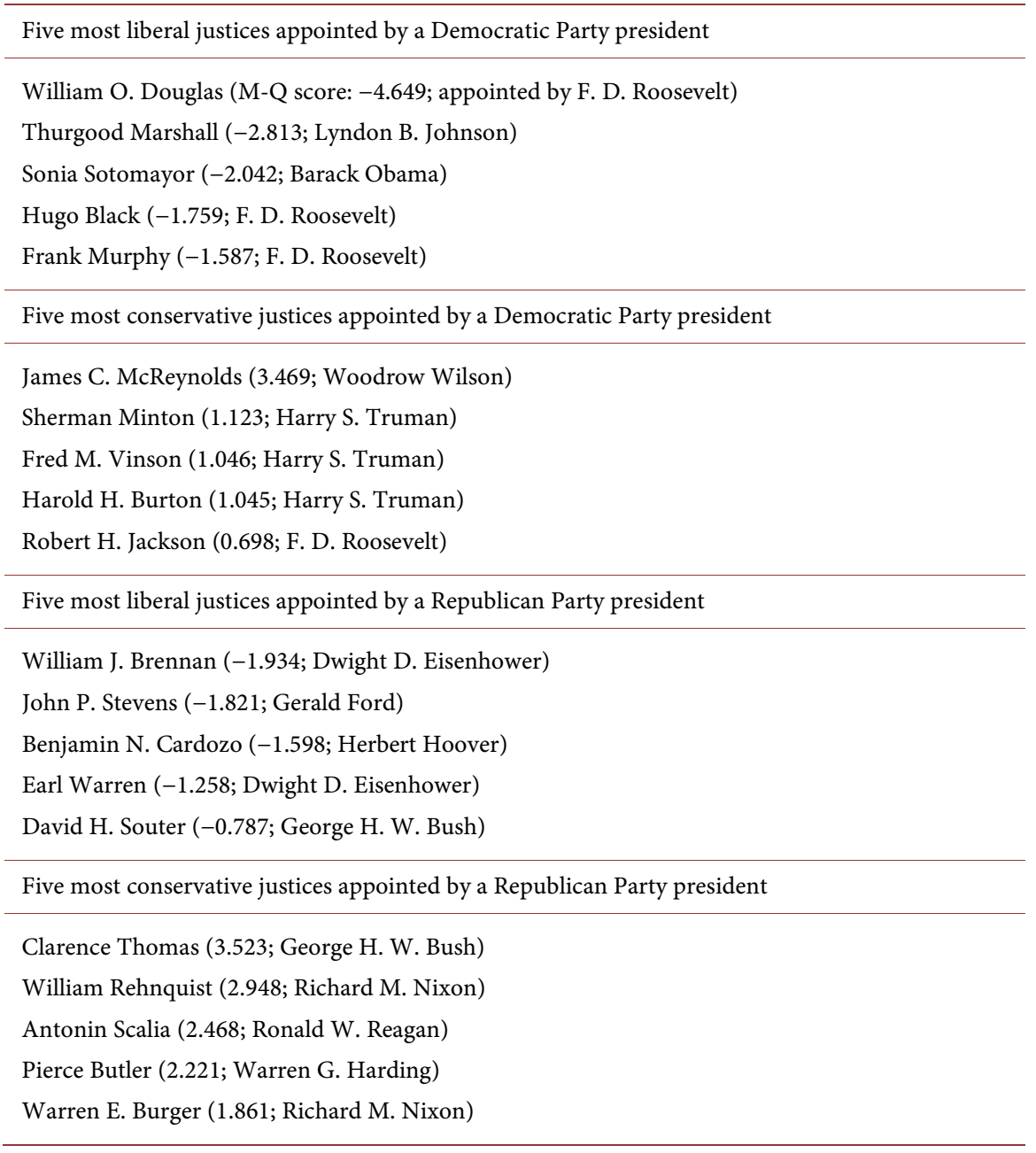

Source: Annual scores are from http://mqscores.berkeley.edu/measures.php. Mean scores are based on the length of the justice's career.

time in the Oval Office (between April 12, 1945 and January 20, 1953), three of whom are among the five most conservative justices appointed by a sitting Democratic president since October 1937. By comparison, of the five justices appointed by Dwight D. Eisenhower during his two terms (between January 20, 1953 and January 20, 1961), two are among the five most liberal justices appointed by a Republican president in our sample. Richard M. Nixon was most successful among Republicans stacking the Court with conservatives, while Franklin D. Roosevelt was most successful among Democrats stacking the Court with liberals.

\section{Methodology}

Two modes of statistical analysis- $t$-tests and simple regression-are employed to assess ideological drift among Supreme Court justices since October 1937.

First, we ran a series of one-tailed two-sample $t$-tests on the difference between average M-Q scores of appointees of each political party in each of the 20 
four-year administrations since 1937. The null hypothesis $\left(H_{0}\right)$ is stated as follows:

$$
H_{0}: \mu_{\text {Democratic }}=\mu_{\text {Republican }}
$$

while the one-tailed competing alternative hypothesis $\left(H_{A}\right)$ is:

$$
H_{A}: \mu_{\text {Democratic }}<\mu_{\text {Republican }}
$$

where $\mu$ denotes the average M-Q score of all justices (appointed by a Democratic or a Republican president) for each presidential term. Rejecting $H_{0}$ in favor of $H_{A}$ would suggest that the justices appointed by a Democratic president were markedly more liberal than their Republican counterparts on the Supreme Court during that administration.

Finally, for each of the 34 justices with a minimum of seven years of service, we used STATA to regress the justice's annual $M-Q$ score against $Y e a r$ (a time trend variable), as follows:

$$
M-Q \text { score }=b_{0}+b_{1} \text { Year }
$$

A positive and statistically significant value for $b_{1}$ would suggest that the justice became more conservative over time. Similarly, a negative and statistically significant value for $b_{1}$ would suggest that the justice became more liberal. ${ }^{3}$

\section{Presentation of the Results}

Table 3 summarizes the results of the two-sample $t$-tests which compare the average M-Q scores of Democratic and Republican appointees for each administration since 1937. During Truman's administration (following his election in 1948), all nine justices had been appointed by Democratic presidents, but surprisingly their average M-Q score (0.4592) was positive and statistically discernible from zero $(p=0.011)$. That is, the F. D. Roosevelt appointees (R.H. Jackson, Reed, Black, Frankfurter, Douglas) and Truman appointees (Vinson, Minton, Burton, Clark) were as a group conservative. Moreover, the difference between the average $M-Q$ score of Democratic appointees and that of Republican appointees was not statistically discernible in Eisenhower's $1^{\text {st }}$ term $(1953-1956, p=$ 0.3445) and Clinton's $1^{\text {st }}$ term (1993-1996, $\left.p=0.0574\right)$. However, in all other administrations, justices who were Democratic appointees rendered more liberal decisions (i.e., their average M-Q scores were significantly lower) than their Republican-appointed counterparts. And, these differences were most pronounced during Roosevelt's third term in office and Obama's two terms in office.

The regression results in Table 4 indicate a significant ideological drift (i.e., $p$ $<0.05$ on the estimated slope coefficient) for 27 of the 34 justices with a minimum of seven years on the Supreme Court.

Nine (two Republican appointees, seven Democratic appointees) became more conservative and eighteen (ten Republican appointees, eight Democratic

${ }^{3}$ If the slope coefficient, $b_{1}$, is not discernible from zero, there is no evidence of a linear trend. Justices who are pigeon-holed in the "no change" category may have made moves to the right (left) followed by change to the left (right). That is, their term-by-term M-Q scores may follow a more complex polynomial fit than a linear one. 
appointees) became more liberal. In all twenty-seven regressions, the simple linear model fits quite well (with $R^{2}$, a measure of the explanatory power of the regression, 0.70 or higher for twenty of the justice-specific regressions).

Table 5 highlights the ideological drift among Supreme Court justices. Among Republican presidents, Nixon appointees (Burger, Blackmun, Rehnquist) and two appointees each by Eisenhower (Warren, Brennan), Reagan (O'Connor, Kennedy), and George H. W. Bush (Souter, Roberts) became more liberal. Only one of Coolidge's appointees (Stone) and Hoover's appointees (O.J. Roberts) became more conservative. Among Democratic presidents, four of Roosevelt's appointees (Black, Reed, Frankfurter, Jackson) and two of Truman's appointees (Burton, Vinson) became more conservative. Two appointees each by Roosevelt (Douglas, Rutledge), Truman (Clark, Minton), and Clinton (Ginsburg, Breyer) became more liberal. The trend toward conservatism (Black, Reed, Frankfurter) and that toward liberalism (Clark, Warren, Blackmun) are in general agreement with results obtained by Martin and Quinn [4] and Epstein et al.

Table 3. Average Martin-Quinn Scores of Supreme Court Justices, 1937-2015, by Administration and Party of the President.

\begin{tabular}{|c|c|c|c|c|c|c|}
\hline \multirow[t]{2}{*}{ Administration } & \multirow[t]{2}{*}{ Years } & \multicolumn{2}{|c|}{$\begin{array}{l}\text { Combined justice-years } \\
\text { Justice appointed by }\end{array}$} & \multicolumn{2}{|c|}{$\begin{array}{c}\text { Average } \\
\text { Martin-Quinn } \\
\text { Score }\end{array}$} & \multirow{2}{*}{$\begin{array}{c}\text { p-value } \\
\text { on difference } \\
\text { between } \\
\text { means }^{\mathrm{a}}\end{array}$} \\
\hline & & Republican (R) & Democrat (D) & $\mathrm{R}$ & $\mathrm{D}$ & \\
\hline F.D. Roosevelt $\left(2^{\text {nd }}\right)$ & $1937-1940$ & $16^{\mathrm{b}}$ & 22 & 0.3638 & -0.8934 & 0.0264 \\
\hline F.D. Roosevelt $\left(3^{\text {rd }}\right)$ & $1941-1944$ & 8 & 28 & 1.3723 & -1.0639 & $<0.0001$ \\
\hline Roosevelt/Truman & $1945-1948$ & 1 & 35 & 0.7260 & -0.3710 & - \\
\hline Truman & 1949-1952 & 0 & 36 & - & 0.4592 & - \\
\hline Eisenhower $\left(1^{\text {st }}\right)$ & $1953-1956$ & 9 & 29 & 0.0893 & -0.1672 & 0.3445 \\
\hline Eisenhower $\left(2^{\text {nd }}\right)$ & $1957-1960$ & 19 & 18 & 0.2178 & -1.0821 & 0.0364 \\
\hline Kennedy/Johnson & $1961-1964$ & 17 & 20 & 0.1539 & -1.6429 & 0.0084 \\
\hline Johnson & $1965-1968$ & 16 & 20 & -0.1171 & -1.8710 & 0.0129 \\
\hline Nixon $\left(1^{\text {st }}\right)$ & 1969-1972 & 22 & 14 & 1.0815 & -2.2881 & 0.0001 \\
\hline Nixon/Ford & $1973-1976$ & 26 & 11 & 1.0211 & -2.5604 & 0.0002 \\
\hline Carter & $1977-1980$ & 28 & 8 & 0.5892 & -1.5265 & 0.0058 \\
\hline Reagan $\left(1^{\text {st }}\right)$ & 1981-1984 & 28 & 8 & 0.6977 & -1.5626 & 0.0053 \\
\hline Reagan $\left(2^{\text {nd }}\right)$ & 1985-1988 & 28 & 8 & 0.3519 & -1.5665 & 0.0197 \\
\hline G.H.W. Bush & 1989-1992 & 30 & 6 & 0.6161 & -1.0128 & 0.0349 \\
\hline Clinton $\left(1^{\text {st }}\right)$ & 1993-1996 & 29 & 7 & 0.8723 & -0.4519 & 0.0574 \\
\hline Clinton $\left(2^{\text {nd }}\right)$ & $1997-2000$ & 28 & 8 & 0.9478 & -1.0161 & 0.0115 \\
\hline G.W. Bush $\left(1^{\text {st }}\right)$ & 2001-2004 & 28 & 8 & 0.6692 & -1.4764 & 0.0057 \\
\hline G.W. Bush $\left(2^{\text {nd }}\right)$ & $2005-2008$ & 29 & 8 & 0.7398 & -1.4806 & 0.0028 \\
\hline Obama $\left(1^{\text {st }}\right)$ & 2009-2012 & 21 & 15 & 1.5363 & -1.6849 & $<0.0001$ \\
\hline Obama $\left(2^{\text {nd }}\right)^{\mathrm{c}}$ & 2013-2015 & 15 & 12 & 1.2903 & -1.9744 & $<0.0001$ \\
\hline
\end{tabular}

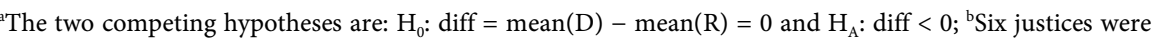
appointed by a Republican president and served a combined total of 16 years between 1937 and 1940 [Pierce Butler (2), Benjamin N. Cardozo (1), Charles E. Hughes (4), Owen J. Roberts (4), Harlan F. Stone (4), and George Sutherland (1)]. 'Obama's second term through 2015. 
Table 4. Summary of Regression Results, Justices with a Minimum of Seven Years of Service since 1937.

\begin{tabular}{|c|c|c|c|c|c|}
\hline Justice & Appointed by & Constant $\left(\mathrm{b}_{0}\right)$ & Slope $\left(b_{1}\right)$ & $R^{2}$ & Terms \\
\hline H. F. Stone & Coolidge (R) & $-395.400(-6.93)^{1 \star}$ & $0.204(6.93)^{*}$ & 0.873 & $9^{a}$ \\
\hline O. J. Roberts & Hoover (R) & $-777.092(-14.18)^{*}$ & $0.401(14.21)^{\star}$ & 0.971 & $8^{\mathrm{a}}$ \\
\hline H. Black & F. D. Roosevelt (D) & $-169.810(-9.67)^{\star}$ & $0.086(9.57)^{*}$ & 0.741 & 34 \\
\hline S. F. Reed & F. D. Roosevelt (D) & $-273.801(-10.58)^{*}$ & $0.141(10.60)^{*}$ & 0.862 & 20 \\
\hline F. Frankfurter & F. D. Roosevelt (D) & $-173.504(-5.71)^{\star}$ & $0.089(5.72)^{*}$ & 0.598 & 24 \\
\hline W. O. Douglas & F. D. Roosevelt (D) & $368.394(12.92)^{*}$ & $-0.191(-13.08)^{\star}$ & 0.826 & 38 \\
\hline F. Murphy & F. D. Roosevelt (D) & $2.889(0.10)$ & $-0.002(-0.16)$ & 0.003 & 10 \\
\hline R. H. Jackson & F. D. Roosevelt (D) & $-124.852(-2.81)^{\star \star \star}$ & $0.065(2.83)^{\star * *}$ & 0.421 & 13 \\
\hline W. B. Rutledge & F. D. Roosevelt (D) & $241.918(5.12)^{*}$ & $-0.125(-5.15)^{*}$ & 0.841 & 7 \\
\hline H. H. Burton & Truman (D) & $-105.241(-5.04)^{\star}$ & $0.055(5.10)^{*}$ & 0.684 & 14 \\
\hline F. M. Vinson & Truman (D) & $-391.190(-9.25)^{*}$ & $0.201(9.28)^{*}$ & 0.945 & 7 \\
\hline T. C. Clark & Truman (D) & $119.832(4.42)^{*}$ & $-0.061(-4.40)^{*}$ & 0.548 & 18 \\
\hline S. Minton & Truman (D) & $191.771(4.29)^{\star \star}$ & $-0.098(-4.27)^{\star \star}$ & 0.752 & 8 \\
\hline E. Warren & Eisenhower (R) & $89.320(2.14)^{\star * *}$ & $-0.046(-2.17)^{\star * *}$ & 0.253 & 16 \\
\hline J. Harlan II & Eisenhower (R) & $11.396(0.17)$ & $-0.005(-0.15)$ & 0.001 & 17 \\
\hline W. J. Brennan & Eisenhower (R) & $186.074(16.85)^{*}$ & $-0.095(-17.03)^{*}$ & 0.901 & 34 \\
\hline P. Stewart & Eisenhower (R) & $7.535(0.59)$ & $-0.004(-0.55)$ & 0.014 & 23 \\
\hline B. R. White & Kennedy (D) & $-67.166(-5.65)^{\star}$ & $0.034(5.69)^{*}$ & 0.519 & 32 \\
\hline T. Marshall & L. B. Johnson (D) & $349.587(18.51)^{*}$ & $-0.178(-18.66)^{*}$ & 0.941 & 24 \\
\hline W. E. Burger & Nixon (R) & $77.752(2.49)^{\star * \star}$ & $-0.038(-2.43)^{\star * \star}$ & 0.282 & 17 \\
\hline H. Blackmun & Nixon (R) & $292.949(25.97)^{*}$ & $-0.148(-25.98)^{\star}$ & 0.967 & 25 \\
\hline L. Powell & Nixon (R) & $43.599(1.84)$ & $-0.022(-1.80)$ & 0.187 & 16 \\
\hline W. Rehnquist & Reagan, Nixon (R) & $229.340(16.27)^{*}$ & $-0.114(-16.06)^{\star}$ & 0.890 & 34 \\
\hline J. P. Stevens & Ford (R) & $218.245(11.02)^{*}$ & $-0.111(-11.11)^{*}$ & 0.789 & 35 \\
\hline S. D. O'Connor & Reagan (R) & $128.824(11.74)^{\star}$ & $-0.064(-11.65)^{\star}$ & 0.855 & 25 \\
\hline A. Scalia & Reagan $(\mathrm{R})$ & $33.531(1.21)$ & $-0.016(-1.12)$ & 0.043 & 30 \\
\hline A. Kennedy ${ }^{\mathrm{b}}$ & Reagan $(\mathrm{R})$ & $93.903(10.12)^{*}$ & $-0.047(-10.05)^{*}$ & 0.789 & 29 \\
\hline D. Souter & G. H. W. Bush (R) & $274.693(10.96)^{*}$ & $-0.138(-10.99)^{*}$ & 0.877 & 19 \\
\hline C. Thomas ${ }^{\mathrm{b}}$ & G. H. W. Bush (R) & $23.158(1.21)$ & $-0.010(-1.02)$ & 0.044 & 25 \\
\hline R. B. Ginsburg ${ }^{\mathrm{b}}$ & Clinton (D) & $189.698(13.35)^{*}$ & $-0.095(-13.46)^{*}$ & 0.896 & 23 \\
\hline S. Breyer ${ }^{\mathrm{b}}$ & Clinton (D) & $88.448(7.23)^{*}$ & $-0.045(-7.32)^{*}$ & 0.728 & 22 \\
\hline J. Roberts ${ }^{\mathrm{b}}$ & G. W. Bush (R) & $219.360(5.46)^{*}$ & $-0.109(-5.43)^{\star}$ & 0.766 & 11 \\
\hline S. Alito ${ }^{\mathrm{b}}$ & G. W. Bush (R) & $-15.187(-0.33)$ & $0.008(0.36)$ & 0.015 & 11 \\
\hline S. Sotomayor ${ }^{\mathrm{b}}$ & Obama (D) & $370.537(10.08)^{*}$ & $-0.185(-10.14)^{*}$ & 0.954 & 7 \\
\hline
\end{tabular}

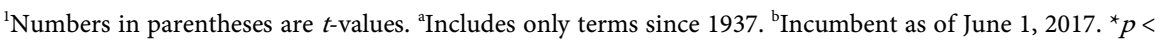
$0.001{ }^{* *} p<0.01 ;{ }^{* * *} p<0.05$. 
Table 5. Evolution of Justices' Decisions, 1937-2015 .

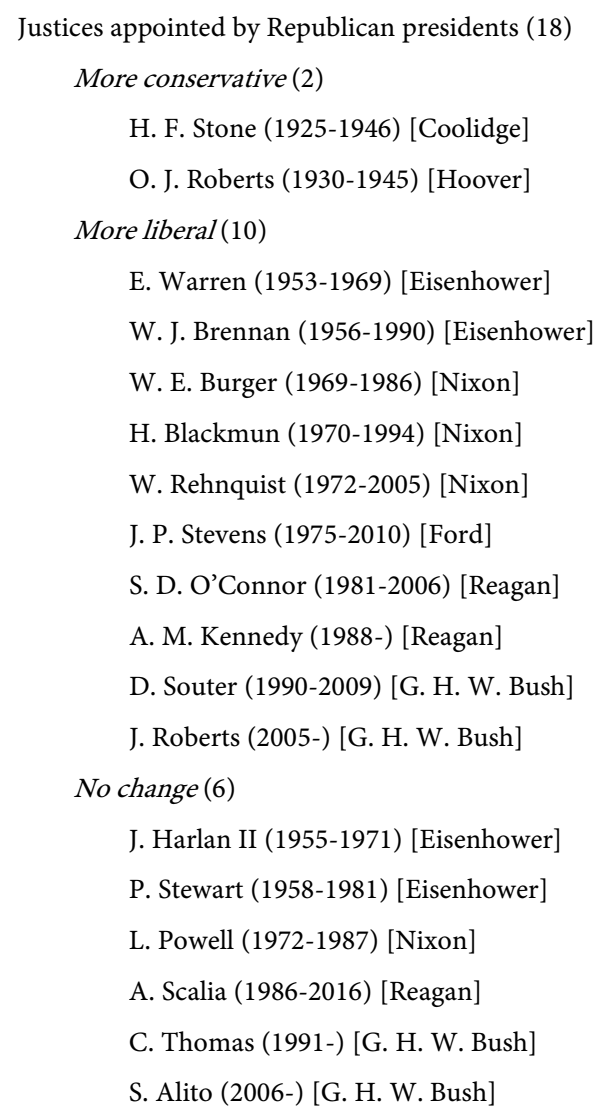


[5] who used a more mathematically sophisticated Bayesian dynamic ideal point model. By contrast to these two earlier studies, we find that Powell and Scalia demonstrated no significant change, while Burton is significantly more conservative and Breyer is more liberal. We also note that B. R. White, whose final year on the Court was in 1993, is the last justice who drifted to the right and was appointed by a Democratic president. By comparison, since 1993, seven of the ten justices who drifted to the left were appointed by a Republican president.

Potter Stewart (1958-1981), an Eisenhower appointee, demonstrated no significant change in ideology during his tenure on the Court. But, his $\mathrm{M}-\mathrm{Q}$ score relative to the Court average varied from year to year, ranging from a $z$-value as low as 0.025 to as high as $0.645 .{ }^{4}$ Hugo Black (1937-1971), a F. D. Roosevelt appointee who became more conservative during his tenure on the Court, had $z$-values as low as -1.704 (in 1960) and as high as 0.546 (in 1968). Harry Blackmun (1970-1994), a Nixon appointee who became more liberal during his tenure, had $z$-values as low as -1.305 (in 1992) and as high as 0.770 (in 1970). These three justices underscore an area for future research that employs $z$-values to assess ideological shift. Another question we leave for further research is: Does a justice-specific $z$-value vary with the party of the president in office? That suggests that a Democratic appointee may be more conservative relative to the rest of the Court (that is, his or her $z$-value will be higher) when a Republican occupies the Oval Office.

\section{Concluding Remarks}

President Truman once remarked: "Whenever you put a man on the Supreme Court, he ceases to be your friend." Due to the lifetime tenure of Supreme Court justices, it is difficult to predict ideological change throughout their respective terms.

Using Martin-Quinn scores on Supreme Court justices, the results presented here show that the party which controls the White House obviously makes a difference: Democrats appoint liberal justices and Republicans appoint conservatives. The main contribution of this research is that there is not only ideological drift among these justices, but in many instances ideological reversal. Simple regression models show that the degree of ideological reversal among Supreme Court justices appointed since 1937 has been remarkable. Ten of the eighteen justices appointed by Republican presidents became more liberal and seven of the sixteen justices appointed by Democratic presidents became more conservative. In other words, the ideologies of half of the Supreme Court justices (with a minimum of seven years of service since 1937) reversed direction. The chance that President Trump's appointee (or future appointees) to the Court will remain faithful to conservative values may not be better than a coin toss.

With the recent addition of Neil Gorsuch to the Supreme Court, five of the

${ }^{4} \mathrm{~A} Z$-value represents the number of standard deviations the justice's own M-Q score is from the mean M-Q score of all nine justices that term. A positive (negative) $z$-value, for example, would imply that the justice was more conservative (liberal) than the entire Court that term. The appeal of using $z$-values is that an apparent centrist could be revealed as conservative on a liberal Court. 
current nine justices are Republican president appointees. The practical social significance of our findings lies partially in the fate of President Trump's "travel ban" and other forthcoming Court cases. Their outcomes may disappoint today's conservative leadership in the two other branches of government. Of equal relevance are rumors of centrist Anthony Kennedy's impending retirement, which in the present administration could move the Court decisively to the right. Yet, the frequency of ideological reversal may frustrate Republican efforts to secure a lastingly conservative Supreme Court.

\section{References}

[1] Gunther, G. (1985) Constitutional Law. 11th Edition, The Foundation Press, Mineola, New York.

[2] Martin, A.D. and Quinn, K.M. (2002) Dynamic Ideal Point Estimation via Markov Chain Monte Carlo for the U.S. Supreme Court 1953-1999. Political Analysis, 10, 134-153. https://doi.org/10.1093/pan/10.2.134

[3] Martin-Quinn Scores, N.p. http://mqscores.berkeley.edu/measures.php

[4] Martin, A.D. and Quinn, K.M. (2007) Assessing Preference Change on the U.S. Supreme Court. The Journal of Law, Economics, and Organization, 23, 303-325. https://doi.org/10.1093/jleo/ewm028

[5] Epstein, L., Martin, A.D., Quinn, K.M. and Segal, J.A. (2007) Ideological Drift among Supreme Court Justices: Who, When, and How Important? Northwestern University Law Review, 101, 1483-1541.

http://scholarship.law.berkeley.edu/facpubs/1999

\section{Scientific Research Publishing}

Submit or recommend next manuscript to SCIRP and we will provide best service for you:

Accepting pre-submission inquiries through Email, Facebook, LinkedIn, Twitter, etc. A wide selection of journals (inclusive of 9 subjects, more than 200 journals)

Providing 24-hour high-quality service

User-friendly online submission system

Fair and swift peer-review system

Efficient typesetting and proofreading procedure

Display of the result of downloads and visits, as well as the number of cited articles

Maximum dissemination of your research work

Submit your manuscript at: http://papersubmission.scirp.org/

Or contact jss@scirp.org 